

\section{DISCLAIMER}

This report was prepared as an account of work sponsored by an agency of the United States Government. Neither the United States Government nor any agency Thereof, nor any of their employees, makes any warranty, express or implied, or assumes any legal liability or responsibility for the accuracy, completeness, or usefulness of any information, apparatus, product, or process disclosed, or represents that its use would not infringe privately owned rights. Reference herein to any specific commercial product, process, or service by trade name, trademark, manufacturer, or otherwise does not necessarily constitute or imply its endorsement, recommendation, or favoring by the United States Government or any agency thereof. The views and opinions of authors expressed herein do not necessarily state or reflect those of the United States Government or any agency thereof. 


\section{DISCLAIMER}

Portions of this document may be illegible in electronic image products. Images are produced from the best available original document. 


\title{
IN-PILE TEMPERATURE DEPENDENCE OF THE YIELD STRENGTH AND GROWTH OF ZIRCALOY (AWBA Development Program)
}

C. C. Dollins

March 1978

Contract EY-76-C-11-0014

\author{
Printed in the United States of America \\ Available from the \\ National Technical Information Service \\ U.S. Department of Commerce \\ 5285 Port Royal Road \\ Springfield, Virginia 22151
}

This document is an interim memorandum prepared primarily for internal reference and does not represent a final expression of the opinion of Westinghouse. When this memorandum is distributed externally, it is with the express understanding that Westinghouse makes no representation as to completeness, accuracy, or usability of information contained therein.

\section{BETTIS ATOMIC POWER LABORATORY WEST MIFFLIN, PENNSYLVANIA}

Operated for the U.S. Department of Energy by 
This report was prepared as an account of work sponsored by the United States Government. Neither the United States, nor the United States Department of Energy, nor any of their employees, nor any of their contractors, subcontractors, or their employees, makes any warranty, express or implied, or assumes any legal liability or responsibility for the accuracy, completeness or usefulness of any information, apparatus, product or process disclosed, or represents that its use would not infringe privately owned rights. 


\section{FOREWORD}

The Shippingport Atomic Power Station located in Shippingport, Pennsylvania was the first large-scale, central-station nuclear power plant in the United States and the first plant of such size in the world operated solely to produce electric power. This project was started in 1953 to confirm the practical application of nuclear power for large-scale electric power generation. It has provided much of the technology being used for design and operation of the commercial, central-station nuclear power plants now in use.

Subsequent to development and successful operation of the Pressurized Water Reactor in the AEC-owned reactor plant at the Shippingport Atomic Power Station, the Atomic Energy Commission in 1965 undertook a research and development program to design and build a Light Water Breeder Reactor core for operation in the Shippingport Station. In 1976, with fabrication of the Light Water Breeder Reactor (LWBR) nearing completion the Energy Research and Development Administration established the Advanced Water Breeder Applications program (AWBA) to develop and disseminate technical information which would assist U.S. industry in evaluating the LWBR concept. All three of these reactor development projects have been administered by the Division of Naval Reactors with the goal of developing practical improvements in the utilization of nuclear fuel resources for generation of electrical energy using water-cooled nuclear reactors.

The objective of the Light Water Breeder Reactor project has been to develop a technology that would significantly improve the utilization of the nation's nuclear fuel resources employing the well-established water reactor technology. To achieve this objective, work has been directed toward analysis, design, component tests, and fabrication of a water-cooled, thorium oxide fuel cycle breeder reactor to install and operate at the Shippingport Station. Operation of the LWBR core in the Shippingport Station started in the Fall of 1.977 and is expected to be completed in about 3 to 4 years. Then the fissionable fuell inventory of the core will be measured. This effort, when completed in about 2 to 3 years after completion of LWBR core operation, is expected to confirm that breeding actually took place.

The Advanced Water Breeder Applications (AWBA) project was initiated to develop and disseminate technical information that will assist U.S. industry in evaluating the LWBR concept for commercial-scale applications. The project will explore some of the problems that would be faced by industry in adapting technology confirmed in the LWBR program. Information to be developed includes concepts for commercial-scale prebreeder cores which will produce uranium-233 for light water breeder cores while producing electric power, improvements for breeder cores based on the technology developed to fabricate and operate the Shippingport LWBR core, and other information and technology to aid in evaluating commercial-scale application of the LWBR concept.

Technical information developed under the Shippingport, LWBR, and AWBA projects has been and will continue to be published in technical memoranda, one of which is this present report. 
I. INTRODUCTION

A. Background

B. Scope

II. MODIFIED GROWTH MODEL

A. Low Temperature Growth Predictions

B. Comparison of Low Temperature Growth Predictions with Experimental Data

III. STRENGTHENING UNDER LOW TEMPERATURE IRRADIATION CONDITIONS

IV. COMPARISON OF THEORETICAL PREDICTIONS WITH HIGH TEMPERATURE GROWTH RESULTS

V. CONCLUSIONS

VI. ACKNOWLEDGMENTS

VII. REFERENCES

\section{LIST OF FIGURES}

$\underline{\text { Figure }}$

1

2

3

\section{Title}

Growth Data Versus Neutron Fluence for Specimens Irradiated at $66^{\circ} \mathrm{C}$ (Also shown are the model predictions at $66^{\circ} \mathrm{C}$ and at $280^{\circ} \mathrm{C}$ )

Growth Versus Neutron Fluence for Specimens Irradiated at $66^{\circ} \mathrm{C}$ Having a Texture Factor of 0.333

Growth Versus Fluence for Specimens of Various Textures Irradiated at $343^{\circ} \mathrm{C}$
Page 
A previously reported growth model is modified and low temperature growth predictions in Zircaloy are made to support the proposal that the smaller irradiation damage observed at lower temperature results from the damage sites, or depleted zones. being larger at lower temperatures. This proposal holds that the vacancies making up the zones cannot migrate at the lower temperature and, therefore, cannot condense into small voids or dislocation loops. The larger zones serve as better sinks for interstitials because they have a larger capture radius and, since they contain the same number of vacancies as the smaller. higher temperature zones, they heal faster resulting in less total damage. The resulting theoretical predictions are compared with experimental data and found to be in good agreement.

\title{
IN-PILE TEMPERATURE DEPENDENCE OF THE YIELD STRENGTH AND GROWTH OF ZIRCALOY (AWBA Development Program)
}

\author{
C. C. Dollins
}

\section{INTRODUCTION}

\section{A. Background}

Since Zircaloy is used as a clad material in nuclear reactors, it is desirable to be able to predict the in-pile temperature behavior of the mechanical properties of Zircaloy. Bement (Reference l) irradiated Zircaloy with neutrons at $60^{\circ} \mathrm{C}$. After irradiation to a fluence of $2.27 \times 10^{21} \mathrm{n} / \mathrm{cm}^{2}$, the yield strength was increased by 30,000 to 40,000 psi. Bement also irradiated Zircaloy at $280^{\circ} \mathrm{C}$ to fluences up to $1.45 \times 10^{21} \mathrm{n} / \mathrm{cm}^{2}$ and found that the yield strength was increased by about 60,000 psi, approximately twice that obtained at $60^{\circ} \mathrm{C}$ even though the lower temperature material had experienced a much higher fluence. Yield strength measurements were made at room temperature.

Adamson (Reference 2) measured the in-pile growth of Zircaloy irradiated with neutrons at $66^{\circ} \mathrm{C}, 250^{\circ} \mathrm{C}$, and $282^{\circ} \mathrm{C}$ to fluences up to 2 $\times 10^{21} \mathrm{n} / \mathrm{cm}^{2}$ and observed that the growth at $250^{\circ} \mathrm{C}$ and $282^{\circ} \mathrm{C}$ was about twice that observed at $66^{\circ} \mathrm{C}$

Blewitt (Reference 3) irradiated copper with neutrons at $30^{\circ} \mathrm{C}$ and after a fluence of 1.3 $\times 10^{20} \mathrm{n} / \mathrm{cm}^{2}$ observed a yield strength of $12,000 \mathrm{psi}$. The yield strength was measured at $27^{\circ} \mathrm{C}$. Makin (Reference 4 ) irradiated copper with neutrons at $80^{\circ} \mathrm{C}$ and then tested it at $20^{\circ} \mathrm{C}$ after a Huence of $1.3 \times 10^{20} \mathrm{n} / \mathrm{cm}^{2}$. A yield strength of 35,000 psi was observed, and this was considerably higher than that observed after irradiation at the lower temperature. Similar observations have been made in stainless steel. Bement et al (Reference 5) irradiated AISI 304 stainless steel. At a fluence of $1.5 \times 10^{21} \mathrm{n} / \mathrm{cm}^{2}$, a yield strength increase of 100,000 psi was observed when the stainless steel was irradiated at $282^{\circ} \mathrm{C}$. However, only an increase of about 55,000 psi was observed when it was irradiated at $93^{\circ} \mathrm{C}$. The initial yield strength is about 30,000 psi. At fluences less than $1 \times 10^{20} \mathrm{n} / \mathrm{cm}^{2}$, the yield strength increases are about the same at these two temperatures. All yield strength measurements were made at room temperature.

\section{B. Scope}

The purpose of this report is to consider the effect of irradiation temperature on damage to $\mathrm{Zir}$ caloy and to explain the small amount of growth and strengthening under a low temperature irradiation condition.

Past observations have shown that high temperature irradiation can cause more irradiationinduced damage, such as strengthening, to copper, stainless steel, and Zircaloy than irradiation at low temperatures. Observations have also shown that irradiation-induced growth in Zircaloy is greater when the irradiation occurs at temperatures near $300^{\circ} \mathrm{C}$ than when it occurs at temperatures near $60^{\circ} \mathrm{C}$. It will be shown that the temperature trends of strengthening and growth are the same.

\section{MODIFIED GROWTH MODEL}

\section{A. Low Temperature Depleted Zone Behavior}

Beavan et al (Reference 6) ion-irradiated tungsten at $18^{\circ} \mathrm{K}$. The resulting depleted zones were 30 to $40 \AA$ in diameter. Depleted zones of $40 \AA$ have also been observed by Attardo and Galligan in platinum (Reference 7). The concentration of vacancies within the depleted zones was about 
10 atom percent, making the depleted zone spongy in character. Within the depleted zone the interstitial concentration was about 1 atom percent. Surrounding the zone was a cloud of interstitials 50 to $130 \AA$ away from the depleted zone.

It is assumed that similar zones form in Zircaloy (References 8.and 9) when it is neutron-irradiated at temperatures below $100^{\circ} \mathrm{C}$. If the irradiation were to take place at room temperature or higher, the interstitials would be mobile and almost all of them within the depleted zone would combine with vacancies, reducing the vacancy concentration from about 10 atom percent to about 9 atom percent. Some of the interstitials assumed to be 50 to $130 \AA$ away would also migrate back to the zone but some would escape the zone to go elsewhere. It has been estimated that about 10 percent of the interstitials escape in Zircaloy (Reference 9). Due to the much higher diffusion rate of the interstitials, the interstitial concentration will reach the steadystate "background" value before there is appreriable motion of the vacancies. It has been observed that the vacancies can rearrange themselves into vold-like structures when irradiated at room temperature (Reference 10). When the material is at a temperature where the vacancies are mobile, it is expected that some will migrate out of the region of the depleted zone and thus escape. The remaining vacancies will form clusters with the larger clusters growing at the expense of the smaller clusters until one large cluster exists. This cluster may be voidlike or may collapse into a vacancy dislocation loop.

Once created, the depleted zone is a sink tor point defects created at other depleted zones. Since most of the point defects which escape a zone are interstitials, most of the point defects that arrive at a zone are interstitials. The interstitials heal the zone. The average or typical zone configuration is dependent upon (1) the rate of healing by interstitials from other zones and (2) the rate at which the vacancies of the depleted zone can migrate from their spongy configuration to either a void or a vacancy dislocation loop. In order to rationalize the observations discussed previously, it is proposed here that in zirconium at temperatures near $300^{\circ} \mathrm{C}$ the typical zone is in the form of a void or loop and at or near room temperature the typical zone in the spongy form.

The average length of time for the vacancies of a zone tu seassauge themselvies into a void or a loop is given by

$$
t=\frac{X^{2}}{6 D_{v}}
$$

where $X$ is the radius of the original zone (approximately 15 to $20 \AA$ ) and $D_{v}$ is the vacancy diffusion coefficient.
From Carpenter and Watters (Reference 11), the vacancy diffusion coefficient is given by

$$
D_{v}=10^{-2} \exp (-27660 / R T)
$$

In Reference 9 , it has been estimated that at $300^{\circ} \mathrm{C}$ the depleted zone density is nearly saturated at a density of approximately $5 \times 10^{18} / \mathrm{cm}^{3}$. The number of depleted zones generated per second is given by $\varphi \sum \mathrm{N}_{\alpha}$, where $\varphi$ is the neutron flux, $\Sigma$ is the scattering cross section, and $\mathrm{N}_{0}$ is the number of lattice sites per unit volume. For a neutron flux of $1 \times 10^{14} \mathrm{sec}$, we obtain $1.7 \times 10^{13}$ zones being generated per sec per $\mathrm{cm}^{3}$. Taking $1.7 \times 10^{13} / \mathrm{cm}^{3} \mathrm{sec}$ into $5 \times 10^{18} / \mathrm{cm}^{3}$ gives $3 \times 10^{5} \mathrm{sec}$ as the zone lifetime. Equation (1) predicts that only $2.6 \times 10^{-2}$ seo are required for the vacancies in a $40 \AA$-depleted zone to rearrange themselves from the spongy state to the void or disloration lonp stato at $300^{\circ} \mathrm{C}$. Theieluie, it is reasonable to treat the depleted zones as voids or dislocation loops as has been tone at the highor temperatures (Reference 9). At $66^{\circ} \mathrm{C}$, it requires $5 \times 10^{5} \mathrm{sec}$ for a similar $40 \AA$-diameter zone to condense to a void. This is about twice the zone lifetime previously mentioned. It will be shown that at the lower temperature the lifetime of the zone is half that at $300^{\circ} \mathrm{C}$; consequently, the $5 \times 10^{5} \mathrm{sec}$ required to condense the zone is about four times the zone lifetime. In the $1.5 \times 10^{5} \mathrm{sec}$ zone lifetime, it is anticipated that little condensation takes place. It is therefore reasonable to assume that the effective zone capture radius for point defects would then be 15 to $20 \AA$ at temperatures near $66^{\circ} \mathrm{C}$ as opposed to the approximately $7 \AA$ of the condensed zone at temperatures near $300^{\circ} \mathrm{C}$.

Recently, a growth model (Reference 12) for Zircaloy has been proposed based on point defect interaction with dislocations, dislocation loops, grain boundaries, and depleted zones. In this model, it was assumed that depleted zones were condensed and had an average radius of approximately $7 \AA$. In Reference 12 , it was shown that the loss rate of vacancies to the zones is given by

$$
\frac{d C_{v}}{d t}=4 \pi \times N D_{v}\left[C_{o} \exp \left[\left(E_{F}-E_{b}\right) / k T\right]-C_{v} l^{\prime}\right.
$$

where

$$
\begin{aligned}
\mathbf{r} & =\text { zone radius } \\
\mathbf{N} & =\text { zone density } \\
\mathrm{C}_{0}= & \text { equilibrium vacancy concentration } \\
\mathbf{E}_{\mathrm{F}}= & \text { vacancy formation energy } \\
\mathbf{E}_{\mathrm{b}}- & \text { biudiuy energy between a vacancy and a } \\
& \text { depleted zone } \\
\mathrm{C}_{\mathrm{v}}= & \text { average vacancy concentration in the lat- } \\
& \text { tice }
\end{aligned}
$$


$\mathrm{t}=$ time

$\mathrm{k}=$ Boltzmann's constant

$\mathrm{T}=$ absolute temperature.

In Reference 12, the loss rate of interstitials to the zones is given by

$$
\frac{\mathrm{dC}_{\mathrm{i}}}{\mathrm{dt}}=-4 \pi \times \mathrm{N} \mathrm{D}_{\mathrm{i}} \mathrm{C}_{\mathrm{i}}
$$

where $C_{i}$ is the average interstitial concentration in the lattice and $D_{i}$ is the interstitial diffusion coefficient.

Equations (3) and (4) are for spherical sinks. It will be assumed that a spongy depleted zone can be treated as a spherical sink, since it is unlikely that once a point defect gets into the region of the depleted zone it can escape without bumping into one of the vacancies or vacancy clusters. Therefore, the radius of the zone to be used in Equations (3) and (4) is approximately $20 \AA$ at the lower temperatures.

It was also shown in Reference 12 that the change in the depleted zone density with time is given by

$$
\begin{aligned}
\frac{\mathrm{dN}}{\mathrm{dt}}= & \phi \Sigma \mathrm{N}_{0} \\
& -\frac{\mathrm{N}}{20}\left(4 \pi \times \mathrm{N}_{\mathrm{o}} \mathrm{D}_{\mathrm{i}} \mathrm{C}_{\mathrm{i}}\right. \\
& +4 \pi \times \mathrm{N}_{\mathrm{o}} \mathrm{D}_{\mathrm{v}}\left\{\mathrm { C } _ { \mathrm { o } } \operatorname { e x p } \left[\left(\mathrm{E}_{\mathrm{F}}\right.\right.\right. \\
& \left.\left.\left.\left.-\mathrm{E}_{\mathrm{b}}\right) / \mathrm{kT}\right]-\mathrm{C}_{\mathrm{v}}\right\}\right),
\end{aligned}
$$

where $\phi$ is the neutron flux, $\Sigma$ is the scattering cross section, $\mathrm{N}_{u}$ is the number of lattice sites per unit volume, and 20 is the assumed number of vacancies in the average depleted zone. At early times the first term on the right hand side of equation (5) dominates and the depleted zone density is independent of $r$, but at steady state when $\mathrm{dN} / \mathrm{dt}=0$, the depleted zone density is inversely proportional to $r$. Since the depleted zone density controls the point defect density which in turn controls the rate of growth of the interstitial dislocation loops, the depleted zune density has a large impact on growth.

\section{B. Comparison of Low Temperature Growth Predictions with Experi- mental Data}

Increasing the radius of the depleted zones from $7 \AA$ to $20 \AA$ at lower temperatures in Equations (3), (4), and (5) decreases the depleted zone density. This change was made to the growth model re- ported in Reference 12, and it was observed that the depleted zone density at a fluence of $1 \times 10^{21}$ $\mathrm{n} / \mathrm{cm}^{2}$ decreased from $4.1 \times 10^{18} / \mathrm{cm}^{3}$ at $280^{\circ} \mathrm{C}$ (radius $=7 \AA$ ) to $2.03 \times 10^{18} / \mathrm{cm}^{3}$ at $66^{\circ} \mathrm{C}$ (radius $=20 \AA$ ). The growths predicted at $66^{\circ} \mathrm{C}$ and $280^{\circ} \mathrm{C}$ are shown in Figure 1. The growth values were calculated assuming a neutron flux of $10^{14} \mathrm{n} / \mathrm{cm}^{2} \mathrm{sec}$ and a grain size of $20 \mu \mathrm{m}$.

It has previously been shown that the model is in agreement with data for temperatures near $300^{\circ} \mathrm{C}$ (Reference 12). Also shown in Figure 1 are data of Adamson (Reference 2) obtained at $66^{\circ} \mathrm{C}$. These low temperature data are below the $300^{\circ} \mathrm{C}$ data as the model predicts. It is seen that agreement between theory and the low temperature data is improved by taking into consideration the larger zone radius as considered above. Figure 2 shows similar data for specimens having a texture factor of 0.333 . There is considerable scatter in the growth data at both temperatures near $300^{\circ} \mathrm{C}$ and $66^{\circ} \mathrm{C}$; however, the average of the data taken at each of the two temperatures indicates less growth at $66^{\circ} \mathrm{C}$ as noted in Reference 2 . The f values of the figures refer to the texture of the close-packedhexagonal crystal structure of Zircaloy, and are the fractions of the basal poles aligned in the direction of the growth measurements.

\section{STRENGTHENING UNDER LOW TEMPERATURE IRRADI- ATION CONDITIONS}

The decrease in the yield stress increment caused by irradiation as the temperature is decreased can be explained partially by the fact that more depleted zones are expected at the higher temperature and partially by the fact that at the low temperature the depleted zone is spread out over a larger volume of the lattice. The stress necessary to pull a dislocation out of a depleted zone can be shown to be less for a spongy zone than for a condensed zone for two reasons. First, for a spongy zone the dislocation at any one moment is in contact with far fewer vacancies resulting in a reduced binding energy between the zone and the dislocation, u. Second, to move the dislocation from the center of the zone to the outside of the zone requires movement over a greater distance. The stress to remove the dislocation is approximately given by (Reference 13)

$$
\sigma=c \frac{\mathrm{u}}{\Delta \mathrm{x}}
$$

where

$$
\begin{aligned}
\mathrm{c} & =\mathrm{a} \text { constant } \\
\mathrm{u} & =\text { binding energy } \\
\Delta \mathrm{x} & =\text { half the size of the depleted zone. }
\end{aligned}
$$


A spongy depleted zone has less binding energy and a greater $\Delta x$ and is therefore weaker. The weakening effect, along with the fact that there are fewer depleted zones, explains why irradiation hardening is less at room temperature than at $300^{\circ} \mathrm{C}$. To some extent, the weakening is offset by the fact that the zones are larger hence, a dislocation will interact with a larger percentage of them.

Other factors may also be important. At temperatures near $300^{\circ} \mathrm{C}$ impurity interstitials such as oxygen may migrate to the depleted zones, strengthening them in some way; such migration is not expected at room temperature. The results of Blewitt (Reference 3), Makin (Reference 4), and Bement et al (Reference 5) seem to indicate that the phenomenon is not restricted to Zircaloy.

\section{COMPARISON OF THEORE- TICAL PREDICTIONS WITH IIIGH TEMPERATURE GROWTH RESULTS}

Adamson (Reference 2) also obtained growth results at $343^{\circ} \mathrm{C}$. For this report, these results are assumed to be at the highest temperature for which growth data are available. The results were obtained at a flux of $1 \times 10^{14} \mathrm{n} / \mathrm{cm}^{2}$ sec in specimens with texture factors between 0.10 and 0.17 . The specimens had grain sizes approximately $20 \mu \mathrm{m}$ in diameter. The data are plotted in Figure 3 along with theoretical predictions assuming the model given in Reference 12 with a texture factor of 0.14 . The texture factor of each specimen is shown near each data point. At such a high temperature, the depleted zones are assumed to be completely condensed.

\section{CONCIIISIONS}

Experimental observations have shown that neutron-irradiated, zirconium-base alloys when irradiated at or near room temperature show a smaller increase in strength and less growth than when irradiated at temperatures near $300^{\circ} \mathrm{C}$. It has been postulated and subsequently demonstrated that this could be due in part to the more diffuse nature of the depleled zones at the lower temperatures. The diffuse or spongy zones at low temperaluies heal faster and hold dislocations less tightly. Both phenomena resull in reduced irradiation strengthening when compared to high temperature results. The smaller number of depleted zones at low temperatures result in fewer uncompensated interstitials available to cause growth by migration to interstitial dislocation lonps, dislosations, and grain boundaries; therefore, growth is less than at higher temperatures where more vacancies are tied up in depleted zones.
Comparisons were made between theoretical predictions of Zircaloy growth and experimental results obtained at $66^{\circ} \mathrm{C}$ and $343^{\circ} \mathrm{C}$ with good agreement.

\section{ACKNOWLEDGMENTS}

The author wishes to express his appreciation to E. A. Zanoni and F. A. Nichols for their many helpful comments.

\section{REFERENCES}

1. A. L. Bement, "Radiation Damage in Hexagonal Close-Packed Metals and Alloys," in Radiation Effects, ed. by W. F. Sheely, p. 671, Gordon and Breach, New York, 1967.

2. R. B. Adamson, "Irradiation Growth of Zircaluy," lu be published in an AS'I'M Special Terhnir:al Publication.

3. T. H. Blewitt, "Low Temperature Irradiation Studies," in Radiation Damage in Solids, ed. by D. S. Billington, Academic Press, London, 1962.

4. M. J. Makin, "Radiation Damage in FaceCentered Cubic Metals and Alloys," in Radiation Effects, ed. by W. F. Sheely, p. 627 , Gordon and Breach, New York, 1967.

5. A. L. Bement, J. E. Irvin, R. G. Hoagland, K. R. Wheeler, and J. W. Carter, "Irradiation Damage to Stainless Steels," G. E. Prog. Rpt. HW 78962, 1963, p. 484.

6. L. A. Beavan, R. M. Scanlan, aud D. N. 3eldman, "l'he Defect Structure of Depleted Zones in Irradiated Tungsten," Acta Met., 19, 1339 (1971).

7. M. J. Attardo and J. M. Galligan, "Annealing Studies of Irradiated Platinum," Phys. Rel., 161, 558 (1967).

8. F. A. Nichols, "Theury of the Creep of Zircaloy During Neutron Irradiation," J. Nucl. Mater, 30. 249 (1969)

9. C. C. Dollins, "Depleted Zone Formation and Recovery During Neutron Irradiation," Radiation Effects, 11, 33 (1971).

10. J. A. Hudson, B. L. Dury, and B. Ralph, "Field Ion Microscupe Examination of Heavy Ion Radiation Damage in Iridium II Analysis of Vacancy Distributions," Phil. Mag., 21, 779 (1970). 
11. G. J. C. Carpenter and J. F. Watters, "Vacancy Precipitation in Zirconium Alloys," Acta Met. 21, 1207 (1973).

12. C. C. Dollins, "In-Pile Dimensional Changes in Neutron Irradiated Zirconium. Base Alloys," J. Nucl. Mater, 59, 61 (1976).

13. J. Friedel, "Dislocations," p. 34, AddisonWesley, Reading, Mass, 1964. 


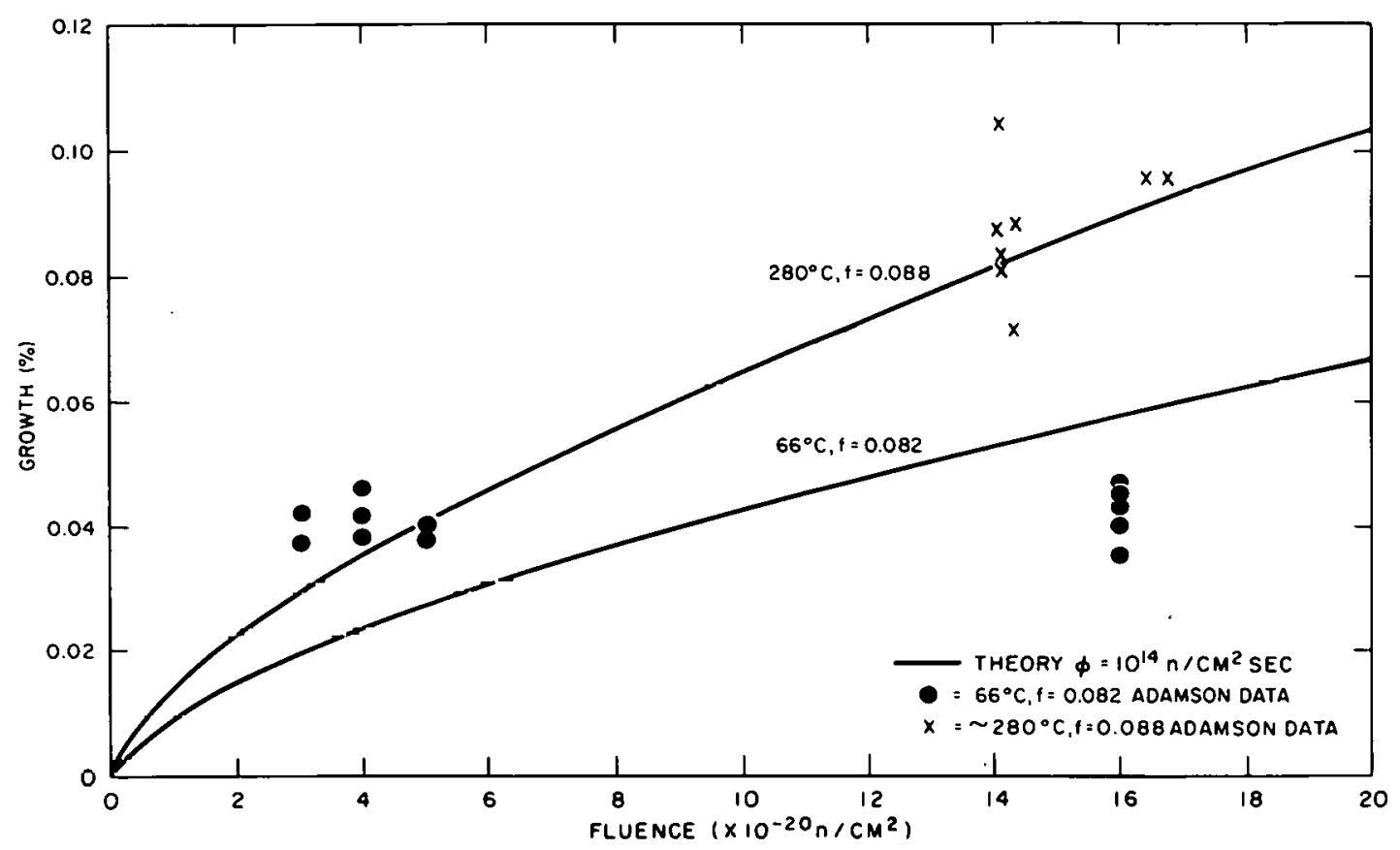

Figure 1. Growth Data Versus Neutron Fluence for Specimens Irradiated at $66^{\circ} \mathrm{C}$ (Also shown are the model predictions at $66^{\circ} \mathrm{C}$ and at $\left.280^{\circ} \mathrm{C}\right)$

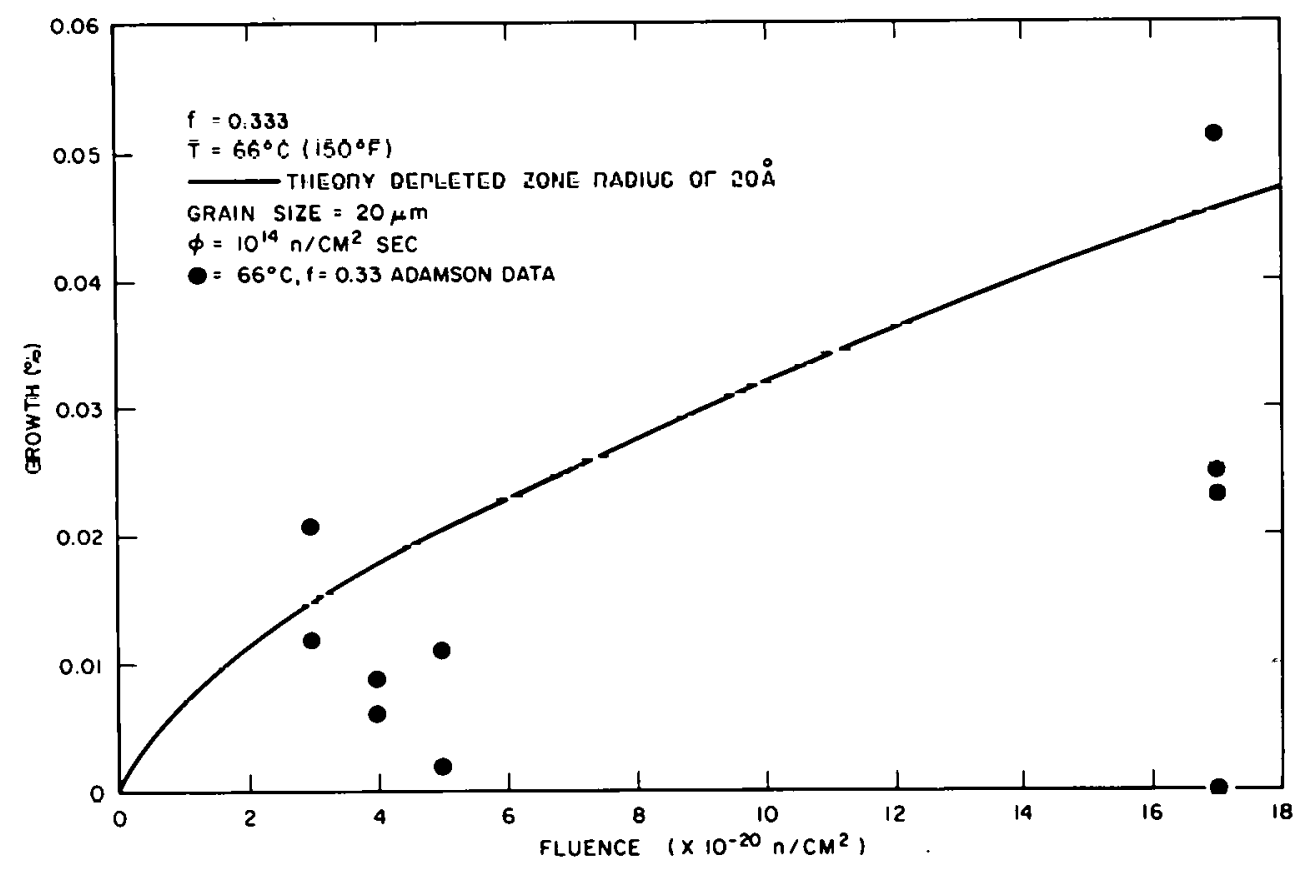

Figure 2. Growth Versus Neutron Fluence for Specimens Irradiated at $66^{\circ} \mathrm{C}$ Having a Texture Factor of 0.333 


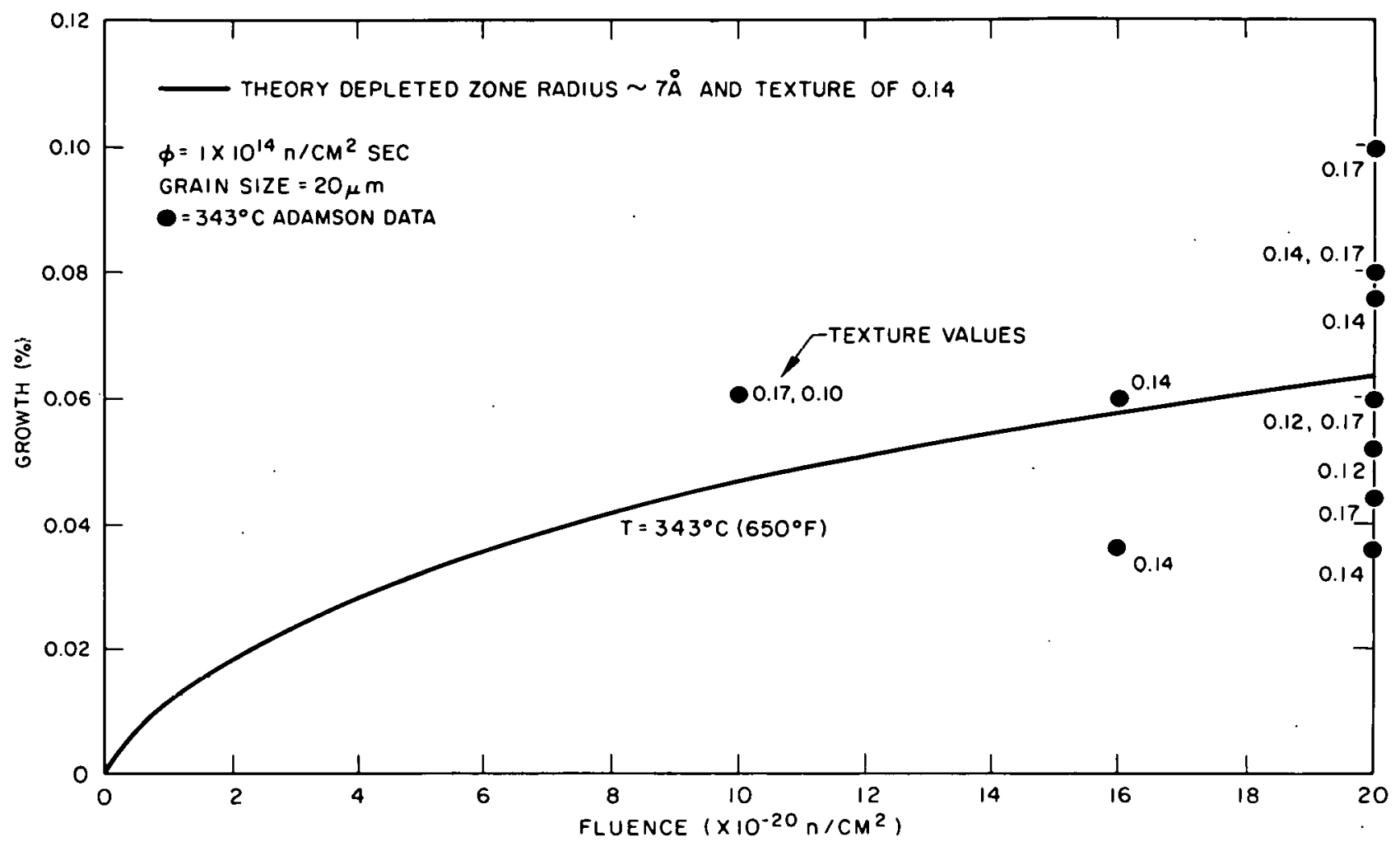

Figure 3. Growth Versus Fluence for Specimens of Various Textures Irradiated at $343^{\circ} \mathrm{C}$

AU.S. GOVERNMENT PRINTING OFFICE: 1978-703-115/325 